\title{
The size of pig embryos is not influenced by their sex by day- 10 after insemination
}

\author{
D. Lechniak' ${ }^{1}$, S.E. Long ${ }^{2}$, A.K. Nissen ${ }^{3}$ and M. Bailey ${ }^{2}$ \\ 'August Cieszkowski Agricultural University, \\ Department of Genetics and Animal Breeding \\ Wolyńska 33, 60-637 Poznan, Poland \\ ${ }^{2}$ University of Bristol, Department of Clinical Veterinary Science \\ Langford House, Langford, BS18 7DU Bristol, England \\ ${ }^{3}$ Royal Veterinary and Agricultural University, \\ Department of Clinical Studies and Reproduction \\ Bulowsvej 13, 1870 Frederiksberg, Denmark
}

(Received 12 May 1999; accepted 13 January 2000)

\begin{abstract}
The extent of embryonic death in preimplantation period in the pig may reach even $40 \%$. Several factors contribute to this phenomenon (onset of oestrogen production, uterine space, chromosomal inbalance). The aim of the present study was to clarify whether genetic sex influences the development of pig embryos in the preimplantation period since the already published data is not consistent. Porcine embryos were flushed out post mortem on day- 10 after insemination, photographed and individually frozen. DNA was extracted from 91 embryos and sex examined by use of PCR method with pair of primers corresponding to the SRY gene. $94.5 \%$ of embryos were succesfully sexed. Embryonic perimeter was measured by means of computer aided programme and sexed embryos were classified and grouped into three categories: small, medium and large, accorrding to their perimeter. According to statistical analysis, embryonic size was not influenced by genetic sex. The ovcral sex ratio, females to males (1.4:1) was not significantly different from the expected 1:1. Moreover, no significant difference between the percentage of males and females was found in the three categories.
\end{abstract}

KEY WORDS: day-10 pig embryos, sex, PCR, size diversity

\section{INTRODUCION}

The proportion of embryos that die during early gestation in the pig ranges from 25 to $40 \%$ (Pope et al., 1990; Lambert et al., 1991). Early investigations were 
concentrated on chromosomal abnormalities as a potential source of this loss but few such anomalies were detected (McFeely, 1967; Smith, and Marlow, 1971; Moon et al., 1975; Dolch and Chrisman, 1981; Hoeven et al., 1985). Furthermore it was shown that many of the chromosome anomalies that were found were only in the trophloblast and not the embryo itself (Long and Williams, 1982) and it was concluded that gross chromosome abnormalities were not a major cause of early embryonic death in the pig. As has been suggested by Roberts et al. (1993) asynchrony within a litter is caused by the losses of conceptuses that are genetically normal but which are lagging in their development. More recently, interest has focused on the effect of asynchronous development of the embryo and uterine environment. It has been suggested that within a litter the more developed embryos start to produce oestrogen, and thus advance uterine secretions, to the detriment of their smaller, slower growing littermates (Dziuk, 1985; Pope et al., 1988). The question remains, however, as to why some embryos are faster growing than others.

It its known that in cattle there is a sex difference in the rate of early cleavage of blastocysts in vivo (Avery et al., 1989) as well as in vitro (Avery et al., 1991; Xu et al., 1992; Yadav et al., 1993). A similar sex difference occurs in the rate of growth of pre-implantation stages in the mouse (Valdivia et al., 1993) with males growing faster than females and it is assumed that it is the embryonic genome that is the controlling factor. Similar investigations in the pig have produced conflicting results. Some reports have not shown the sex dependent relationship in the embryonic size (Stumpf et al., 1994; Pomp et al., 1995; Kaminski et al., 1996) whereas that of Cassar et al. (1994) proved that hypothesis.

The aim of the present study was to clarify whether genetic sex influences the development of pig embryos in the preimplantation period.

\section{MATERIAL AND METHODS}

\section{Embryo collection}

Pure bred Duroc boar semen was used to inseminate Landrace $x$ Yorkshire sows. At day 10 of gestation (day $0=$ day of artificial insemination) the sows were slaughtered, the embryos flushed post mortem, photographed and individually frozen in liquid nitrogen (Nissen et al., 1997).

DNA extraction

The frozen embryos were thawed and digested with proteinase $\mathrm{K}$ (final concentration of $0.2 \mathrm{mg} / \mathrm{ml}$ ) at $55^{\circ} \mathrm{C}$ for $10 \mathrm{~h}$ and then boiled at $100^{\circ} \mathrm{C}$ for $5 \mathrm{~min}$ in 
order to inactivate the enzyme. This procedure was followed by phenol/chlorophorm extraction and ethanol precipitation. The DNA was resuspended in $300 \mu \mathrm{l}$ of water and frozen. All samples were tested for the presence of DNA using a pair of primers corresponding to a pig autosomal repetetive sequence as described by Ellergen et al. (1992).

\section{Embryonic sex determination by $P C R$}

A pair of degenerated primers corresponding to the SRY gene of several domestic species (Griffiths and Tiwari, 1993) were verified on DNA samples derived from 14 adult animals of both sexes and used to sex the pig embryos. The primer sequences were as follows:

\section{RG4 : GGT CAA GCG ACC CAT GAA (C/T) GCN TT \\ RG7 : GGT CGA TAC TTA TAG TTC GGG TA(C/T) TT.}

PCR reactions were carried out using a Techne thermal cycler (model PHC-3) in a final $50 \mu \mathrm{l}$ volume consisting of a $4.0 \mu \mathrm{l}$ aliquot of embryonic DNA template (20-40 ng DNA), $200 \mu \mathrm{M}$ of each dNTP (Perkin Elmer), $1 \mu \mathrm{M}$ of each primer, 5 UI Taq polymerase (Perkin EImer, Prime Zyme), 1xPCR buffer. The optimal conditions for the SRY primers were as follows: 1 cycle at $94^{\circ} \mathrm{C} / 10 \mathrm{~min}$ followed by 50 cycles $\left(94^{\circ} \mathrm{C}\right.$ for $30 \mathrm{sec}, 50^{\circ} \mathrm{C}$ for $30 \mathrm{sec}, 72^{\circ} \mathrm{C}$ for $30 \mathrm{sec}$ ) and finishing with 1 cycle at $72^{\circ} \mathrm{C}$ for $10 \mathrm{~min}$. PCR products were visualised after electrophoresis on $1.5 \%$ agarose gel stained with ethidium bromide.

\section{Embryo measurement}

The photographic negatives were used to measure the perimeter of each embryo by means of a computer aided programme (Vids III Synoptics Cambridge, UK). Embryos within each litter were classified and grouped into three categories: small, medium and large by three equal divisions of the size range between the smallest and largest litter-mates, as suggested by Cassar et al. (1994). This allowed within and between litter comparisons to be made.

\section{Statistical analysis}

Sex ratio was tested by chi-square analysis corrected for small sample size (Yate, 1934), whereas the effect of sex on embryonic size was evaluated with two-factor analysis of variance procedure (PROC GLM of SAS, 1988). 


\section{RESULTS}

A total of 97 day-10 pig embryos from 5 litters were collected, photographed and frozen. The extracted DNA was checked on $1 \%$ agarose gel. In 6 samples no DNA was found and was probably lost during embryo manipulation. The test with pig autosomal primers confirmed the presence of DNA in the remaining 91 samples.

Eighty six of the 91 embryos $(94.5 \%)$ were successfuly sexed using the SRY primers (Table 1). An embryo was classified as male when the $216 \mathrm{bp}$ product corresponding to the SRY gene was present, and as a female when several non specific bands of different lengths (but not $216 \mathrm{bp}$ ) were seen (Figure 1). Each DNA sample was tested in duplicate or triplicate in order to confirm the result (i.e.: male, female) since no autosomal primer was included with the SRY primers. In 6 samples there was insufficient detail on the gels to permit a diagnosis and therefore these were classified as undiagnosed.

Perimeter measurements of the embryos confirmed the great diversity in size amongst pig conceptuses at the same gestational age both within and between litters. This ranged from 1.84 to $33.95 \mathrm{~mm}$ (Table 2). The overal sex ratio, females to males (1.4:1) was not significantly different from the expected $1: 1$ $\left(\chi^{2}=1.82 ; \mathrm{P}>0.05\right)$. When the data from all the litters were pooled there was no statistical difference between the percentage of males and females in the three categories (small $\chi^{2}=1.8 ;$ medium $\chi^{2}=0.4$, large $\chi^{2}=0.04 ; \mathrm{P}>0.05$ ). The percentage of males in each category was: 1 . small embryos $31.3,2$. medium embryos 43.2, 3. large embryos 46.2 (Table 3).

TABLE 1

The results of pig embryo sexing by PCR using SRY primers

\begin{tabular}{|c|c|c|c|c|c|}
\hline \multirow{3}{*}{ Litter } & \multicolumn{5}{|c|}{ Number of embryos } \\
\hline & \multirow{2}{*}{ collected } & \multirow{2}{*}{ analysed } & \multicolumn{3}{|c|}{ sexed } \\
\hline & & & females & males & total \\
\hline I & 26 & 25 & 12 & 12 & 24 \\
\hline II & 29 & 27 & 20 & 7 & 27 \\
\hline III & 17 & 16 & 12 & 3 & 15 \\
\hline IV & 16 & 15 & 3 & 10 & 13 \\
\hline V & 9 & 8 & 3 & 4 & 7 \\
\hline Total & 97 & $\begin{array}{c}91 \\
\text { Sex ratio }\end{array}$ & $\begin{array}{l}50 \\
1.38\end{array}$ & $\begin{array}{r}36 \\
1\end{array}$ & 86 \\
\hline
\end{tabular}




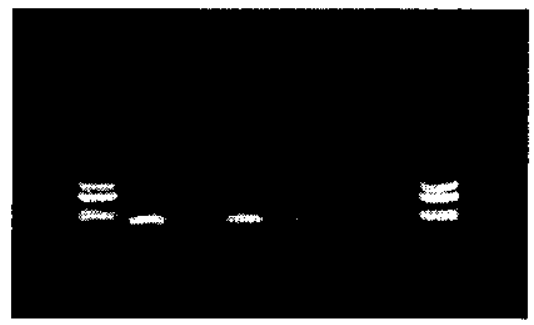

Figure 1. Sex determination of day-10 pig embryos using the SRY primers. Lanes: 1, 8 DNA size marker pUC18 HaeIII; 2, 3 - genomic DNA derived from adult male (2) and female (3); 4-7 embryonic DNA (4,5-males; 6.7 females). The SRY specific band (216bp) is present on all DNA samples of male origin, whereas several nonspecific bands are present on female DNA

TABLE 2

Size diversity among day-10 pig embryos

The range of perimeter in three devclopmental groups, $\mathrm{mm}$

\begin{tabular}{lrrr} 
Litter & \multicolumn{1}{c}{ small } & \multicolumn{1}{c}{ medium } & \multicolumn{1}{c}{ large } \\
\cline { 2 - 4 } I & $2.09-5.21$ & $5.22-8.33$ & $8.34-11.44$ \\
II & $1.49-5.22$ & $5.23-8.96$ & $8.97-12.69$ \\
III & $13.76-17.60$ & $17.61-21.45$ & $21.46-25.29$ \\
IV & $2.22-8.34$ & $8.35-14.47$ & $14.48-20.60$ \\
V & $15.87-21.89$ & $21.9-27.93$ & $27.94-33.95$ \\
\hline
\end{tabular}

TABLE 3

Sex distribution among embryos in the three developmental categories

\begin{tabular}{|c|c|c|c|c|c|c|c|c|c|c|c|c|}
\hline \multirow[b]{3}{*}{ Litter } & \multicolumn{12}{|c|}{ Number of embryos in the three developmental groups } \\
\hline & \multicolumn{4}{|c|}{ small } & \multicolumn{4}{|c|}{ medium } & \multicolumn{4}{|c|}{ large } \\
\hline & $\mathrm{F}$ & $\mathrm{M}$ & total & $\% 1$ & $\mathrm{~F}$ & M & total & $\%^{\prime}$ & $\mathrm{F}$ & M & total & $\%$ \\
\hline 1 & 1 & 0 & 1 & 4.2 & 3 & 4 & 7 & 29.2 & 8 & 8 & 16 & 66.6 \\
\hline II & 4 & 1 & 5 & 18.5 & 12 & 4 & 16 & 59.3 & 4 & 2 & 6 & 22.2 \\
\hline III & 6 & 0 & 6 & 40.0 & 5 & 2 & 7 & 46.7 & 1 & 1 & 2 & 13.3 \\
\hline IV & 0 & 1 & 1 & 7.7 & 3 & 8 & 11 & 84.6 & 0 & 1 & 1 & 7.7 \\
\hline V & 0 & 3 & 3 & 42.9 & 2 & 1 & 3 & 42.9 & 1 & 0 & 1 & 14.2 \\
\hline Total & 11 & 5 & 16 & $18.6^{2}$ & 15 & 19 & 44 & $51.2^{2}$ & 14 & 12 & 26 & $30.2^{2}$ \\
\hline
\end{tabular}

1 the percentage of analysed embryos within litters

2 the percentage of the wholc population of analysed embryos 


\section{DISCUSSION}

The great diversity in embryonic size both within and between litters at analysed gestational age in the pig makes between litter comparisons difficult. Furthermore, since the larger embryos are often eliptical rather than spheroid it is difficult to compare a consistent parameter (Figure 2). We decided that the perimeter, rather than the diameter, of the embryo was better for comparison because this would accommodate both eliptical and spheroid embryos whether or not they were collapsed and flattened. Previous workers measured the diameter of each embryo (Youngs et al., 1994; Pomp et al., 1995; Kamiński et al., 1996) even when the developmental stage suggests that they would not be spherical.
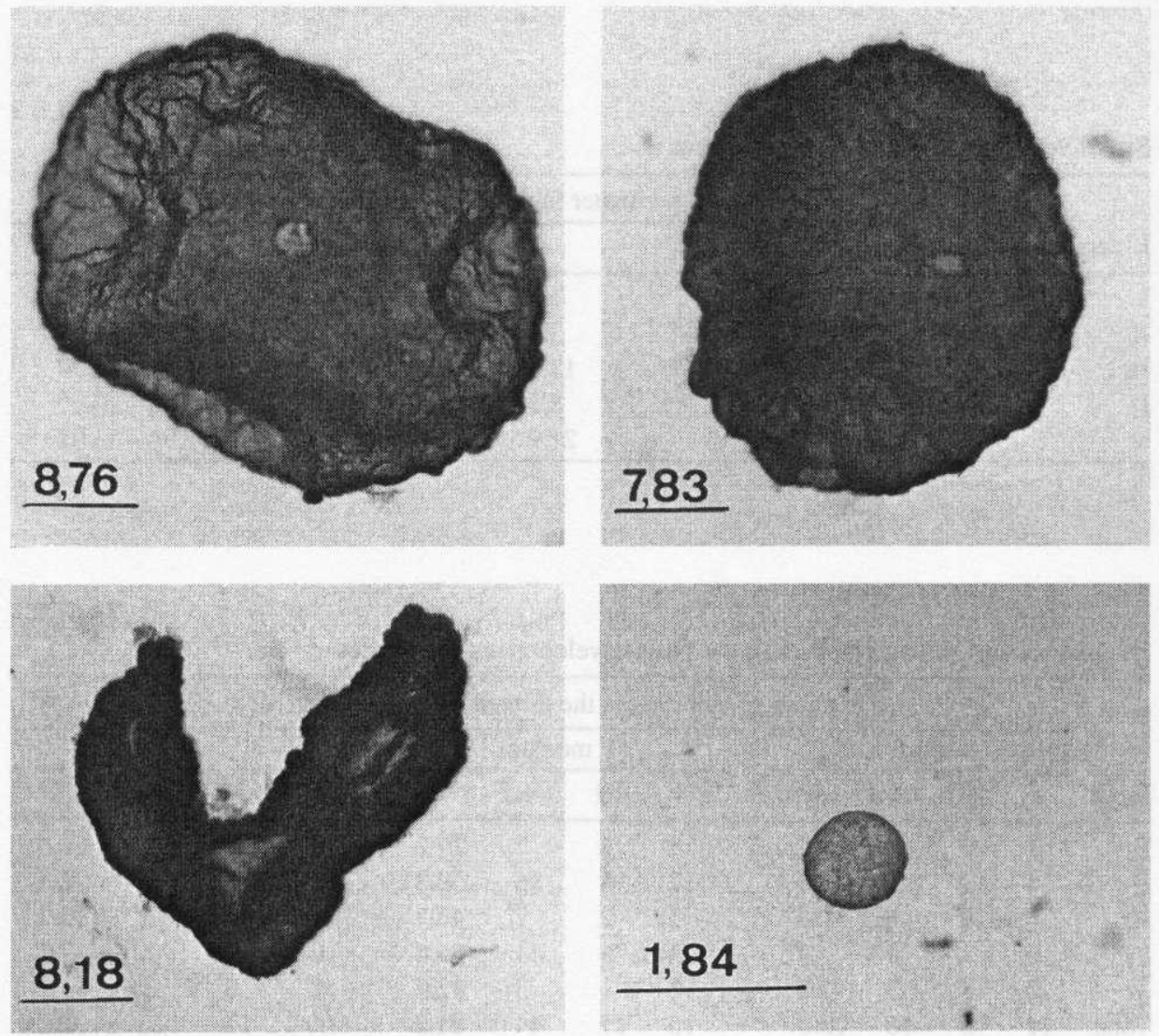

Figure 2. A group of day-10 litter-mate pig embryos analysed in the present study, demonstrating their size (perimeter in $\mathrm{mm}$ ) and shape diversity (the bar represents $1 \mathrm{~mm}$ ) 
Cassar et al. (1994) using cytogenetic method, found that male pig conceptuses were generally larger than female conceptuses on day-10 after mating. The cytogenetic method for sex identification tends to result in a higher percentage of undiagnosed material. Cassar et al. (1994) had a diagnosis rate of only $58 \%$ compared to $100 \%$ (Pomp et al., 1995; Kamiński et al., 1996), 84\% diagnostic rate (Stumpf et al., 1994) and 94.5\% (present study) using molecular techniques. All the previous studies that used PCR for embryo sexing failed to find any relationship between sex and embryonic size at this gestational age (10-12 days after insemination). Our findings agree with these reports.

Each worker however, used different methods of assessing the embryonic size. This presents difficulties in the interpretation and comparison of the different papers. In the work reported by Pomp et al. (1995) whole litters were classified as having either large or small embryos and the within litter variation in embryo size was only $0.2 \mathrm{~mm}$. The work reported by Kaminski et al. (1996) involved reciprocal transfer of embryos from the Meishan and Yorkshire breeds and there were significant interactions between uterine type and embryo breed and embryo size.

The pig would therefore appear to be different from other species investigated in that there is not a sex difference in the growth rate of pre-implantation embryos. Therefore, some other factor or factors must influence the variation in size of embryos at the same gestational age within a litter. As has been shown by Soede et al. (1993) within-litter embryonic diversity was related to the duration of fertilization process and the accessory sperm count. The ovulation span, however, did not influence embryonic diversity at 114-121 h after ovulation (Soede et al., 1992).

\section{REFERENCES}

Avery B., Bak A., Schmidt M., 1989. Differentiated cleavage rates and sex determination in bovine cmbryos. Theriogenology 32, 139-147

Avery B., Madison V., Greve T., 1991. Sex and development in bovine in vitro fertilized embryos. Theriogenology 35, 953-962

Cassar G., King W.A., King G.J., 1994. Influence of sex on early growth of pig conceptuses. J. Reprod. Fertil. 101, 317-320

Dolch K.M., Chrisman C.L., 1981. Cytogenetic analysis of preimplantation blastocysts from prepubertal gilts treated with gonadotropins. Amer. J. Vet. Res. 42, 344-346

Dziuk P., 1985. Effect of migration, distribution and spacing of pig embryos on pregnancy and fetal survival. J. Reprod. Fertil., Suppl. 33, 57-63

Ellegren H., Johansson M., Chowdhary B.P., Marklund S., Ruyter D., Marklund L., Brauner-Nielsen P., Edfors-Lilja I., Gustavsson I., Juneja R.K., Andersson L., 1993 . Assignment of 20 microsatellite markers to the porcine linkage map. Genomics $16,431-439$

Griffiths R., Tiwari B., 1993. Primers for differential amplification of the sex-determining region $\mathrm{Y}$ gene in a range of mammal species. Mol. Ecol. 2, 405-406 
Hoeven van der F.A., Cuijpers M.P, De Boer P., 1985. Karyotypes of 3- or 4- day old pig embryos after short in-vitro culture. J. Reprod. Fertil. 75, 593-597

Kaminski M.A., Ford S.P., Young C.R., Conley A.J., 1996. Lack of effect of sex on pig embryonic development in vivo. J. Reprod. Fertil. 106, 107-110

Lambert E., Williams D.H., Lynch P.B., Hanrahan T.J., McGeady T.A., Austin F.H., Boland M.P., Roche J.F., 1991. The extent and timing of prenatal loss in gilts. Theriogenology 36, 655-665

Long S.E., Williams C.V., 1982. A comparison of the chromosome complement of inner cell mass and trophoblast cells in day 10 pig embryos. J. Reprod. Fertil. 66, 645-648

McFeely R.A., 1967. Chromosome abnormalities in early embryos of the pig. J.Reprod. Fertil. 13, 579-581

Moon R.G., Rashad M.N., Mi M.P., 1975. An example of polyploidy in pig blastocysts. J. Reprod. Fertil. 45, 147-149

Nissen A.K., Soede N.M., Hyttel P., Schmidt M., D'Hoore L.D., 1997. The influence of time of insemination relative to time of ovulation on farrowing frequency and litter size in sows, as investigated by ultrasonography. Theriogenology 47, 1571-1582

Pomp D., Good B.A., Geisert R.D., Corbin C.J., Conley A.J., 1995. Sex identification in mammals with polymerase chain reaction and its use to examine sex effects on diameter of day-10 or -11 pig embryos. J. Anim. Sci. 73, $1408-1415$

Pope W.F., 1988. Uterine asynchrony: a couse of embryonic loss. Biol. Reprod. 39, 999-1003

Pope W.F., Xie S., Broerman D.M. Nephew K.P., 1990. Causes and consequences of early embryonic diversity in pigs. J. Reprod. Fertil., Suppl. 40, 25 I-260

Roberts R.M., Xie S., Trout W.E., 1993. Embryo - uterine interactions in pigs during week 2 of pregnancy. J. Reprod. Fertil, 48, 171-186

Smith J.H., Marlowe T.J., 1971. A chromosomal analysis of 25 day old pig embryos. Cytogenetic 10, 385-391

Soede N.M., Noordhuizen J.P.T.M., Kemp B., 1992. The duration of ovulation in pigs, studied by transrectal ultrasonography, is not related to early embryonic diversity. Theriogenology 38 , 653-666

Soede N.M., Kemp B., 1993. The accessory sperm count is related to early embryonic diversity in pigs. Theriogenology 40, 1057-1064

Stumpf T.T., Prati S.L., Day B.N., 1994 . Does the sex of a porcine embryo affect the rate of development to the blastocyst stage? J. Reprod. Fertil., Abstr. Series 13, Abstr. 118

Valdivia R.P.A., Kunieda T., Azuma S., Toyota L., 1993. PCR sex and developmental rate differences in preimplantation mouse embryos fertlized and cultured in vitro Mol.Reprod. Dev. 35, $121-126$

Yadav B.R., King W.A., Betteridge K.J., 1993. Relationship between the completion of first cleavage and the chromosomal complement, sex and development rates of bovine embryos generated in vitro. Mol. Reprod. Dev. 36, 434-439

Yate F., 1934. Contingency tables involving small numbers and the $\chi^{2}$ test J. Royal Soc., Suppl. $1,217-235$

Youngs C.R., Christensen L.K., Ford S.P., 1994. Investigations into the control of litter size in swine: III. A reciprocal embryos transfer study of early conceptus development, J. Anim. Sci. 72, $725-731$

Xu K.P., Yadav B.R., King W.A., Betteridge K.J., 1992. Sex related differences in developmental rates of bovine embryos produced and cultured in vitro. Mol. Reprod. Dev. 31, 249-252. 


\section{STRESZCZENIE}

\section{Brak związku pomiędzy wielkością i płcią 10-dniowych zarodków świni}

Celem pracy było wyjaśnienie, czy genetyczna płeć zarodka wpływa na tempo rozwoju przedimplantacyjnego u świni, biorąc pod uwagę fakt, że dotychczasowe doniesienia na ten temat były sprzeczne. 10 dnia po inseminacji pięciu loch, wypłukano 97 zarodków, które fotografowano i indywidualnie zamrożono. DNA wyizolowano z 91 zarodków. Płeć $94.5 \%$ z nich określono metodą PCR przy użyciu pary starterów dla genu SRY. Do pomiaru obwodów zarodków wykorzystano negatywy oraz program komputerowy Vids III Synoptics. Płeć oraz rozmiar były podstawą do zaklasyfikowania zarodka do jednej z 3 grup wielkościowych: małej, średniej lub dużej. Ogólny stosunek płci (samce : samice) wyniósł 1.4: 1 i nie różnił się statystycznie od oczekiwanego 1:1. Ponadto nie stwierdzono istotnego wpływu płci zarodka na jego rozmiar oraz różnic między udziałem samców i samic w poszczególnych grupach wielkościowych. 